

\section{Shirkah}

Journal of Economics and Business

Vol. 3, No. 1, January-April 2018

ISSN: 2503-4235 (p); 2503-4243 (e)

\section{Editor in Chief}

Dwi Condro Triono

\section{Managing Editor}

Jasanta Peranginangin

\section{Editorial Boards}

Abdul Azim Islahi,

Islamic Economics Institute, King Abdulaziz University, Saudi Arabia

Abu Umar Faruq Ahmad,

UBD School of Business and Economics Universiti, Brunei Darussalam

Cedomir Nestorovic,

ESSEC Business School Asia Pacific, Singapore

Fitri Wulandari,

Faculty of Islamic Economics and Business, IAIN Surakarta, Indonesia Johan Fischer,

Department of Social Sciences and Business Roskilde Universitetscenter, Denmark Muhamed Zulkhibri,

Islamic Research and Training Institute, Islamic Development Bank, Saudi Arabia M. Kabir Hassan,

Department of Economics and Finance, University of New Orleans, United States Musa Asy'arie,

Faculty of Islamic Economics and Business, IAIN Surakarta, Indonesia

Nunung Nurul Hidayah,

Aston Business School, Aston University, Birmingham, United Kingdom

Saim Kayadibi,

Department of Economics, Kulliyyah of Economics and Management Science, International Islamic University Malaysia, Malaysia 
Shaikh M Ghazanfar,

Departement of Economics, University of Idaho, Russian Federation

Sigit S. Wibowo,

Department of Management, Faculty of Economics and Business, Universitas Indonesia, Indonesia

Vihang R. Errunza,

Desmarais Global Finance Research Centre, Desautels Faculty and Management, McGill University, Canada

\section{Assistant to Editor}

M. Endy Saputro

M. Zainal Anwar

Shirkah Journal of Economics and Business is a peer-reviewed journal published three times a year (January-April, May-August and September-December) by Faculty of Islamic Economics and Business, Institut Agama Islam Negeri (IAIN) Surakarta Central Java, Indonesia. The main objective of Shirkah is to offer an academic space of exchange ideas and initiate the increase number of qualified article produced by postgraduate students, practitioners and academicians.

\section{Editorial Office}

Ruang Jurnal Shirkah

Lantai Dasar, Sayap Barat, Fakultas Ekonomi dan Bisnis Islam, IAIN Surakarta

Jln. Pandawa No. 1, Kartasura, Sukoharjo, Jawa Tengah Kode Pos. 57168

Phone (+62271) 781516 Fax: (+62271)782336

E-mail: shirkahjournal@iainsurakarta.ac.id; shirkahiainsurakarta@gmail.com

Website: http://shirkah.or.id/ 


\section{Shirkah}

Journal of Economics and Business

Vol. 3, No. 1, January-April 2018

ISSN: 2503-4235 (p); 2503-4243 (e)

\section{Table of Contents}

\section{Articles}

Aqeel Akhtar

Fahad Ahmed Qureshi

Mubeen Butt

Laws of Collateral in Today's World in Islamic Perspective

Anton Bawono

Creative Economic Development of Pesantren

Dwi Umardani

Conventional Home Loan and Islamic Home Financing in

Comparative Perspective

Iha Haryani

Dian Riskarini

Tia Ichwani

Business Development Strategy Model of SMEs

through SWOT and EFE-IFE Analysis

Ika Yoga

Halal Emotional Attachment on Repurchase Intention

Anik

Iin Emy Prastiwi

Macro Economic Challenges and Third Party Funds of Islamic Commercial Banks in Indonesia 


\title{
Macro Economic Challenges and Third Party Funds of Islamic Commercial Banks in Indonesia
}

\author{
Anik \\ Sekolah Tinggi Ilmu Ekonomi AAS Surakarta \\ karjunianik@yahoo.co.id \\ Iin Emy Prastiwi \\ Sekolah Tinggi Ilmu Ekonomi AAS Surakarta \\ Iinemyprastiwi24@gmail.com
}

\begin{abstract}
s
This article aims to determine the effect of inflation, the BI Rate, the exchange rate of the rupiah to the US dollar, and the amount of money supply for Third Party Funds (TPF) in Indonesians' Islamic Banks during 2013-2016. This research method uses multiple regression analysis with time series data; gathering data from 48 samples of which are monthly data on the variables. The result of this research find that the inflation and exchange rate variables have no significant effect on TPF, while the BI Rate variable and the money supply have a significant effect on TPF. In doing so, Islamic banking can pay serious attention to the $\mathrm{BI}$ rate and the money supply and in this study the BI rate on the direction of TPF.
\end{abstract}

Keywords: inflation, BI rate, exchange rate, Third Party Funds

\section{Introduction}

The growth of financial institutions, especially Islamic commercial banks, experienced a significant increase in the last few decades. Based on the 2015 Islamic Financial Development report, the asset growth of Islamic Commercial Banks amounted to \pm Rp 304 trillion, up 9\% from the previous year, with a total TPF of \pm Rp 236 trillion, up $6.37 \%$ from the previous year (www.ojk.go.id). On average, most of the bank's total 
assets, including Islamic Commercial Banks, are from the community called Third Party Funds (TPF), as the following 2015 Islamic banking data:

\section{Figure 1. Fund Composition of BUS-UUS}

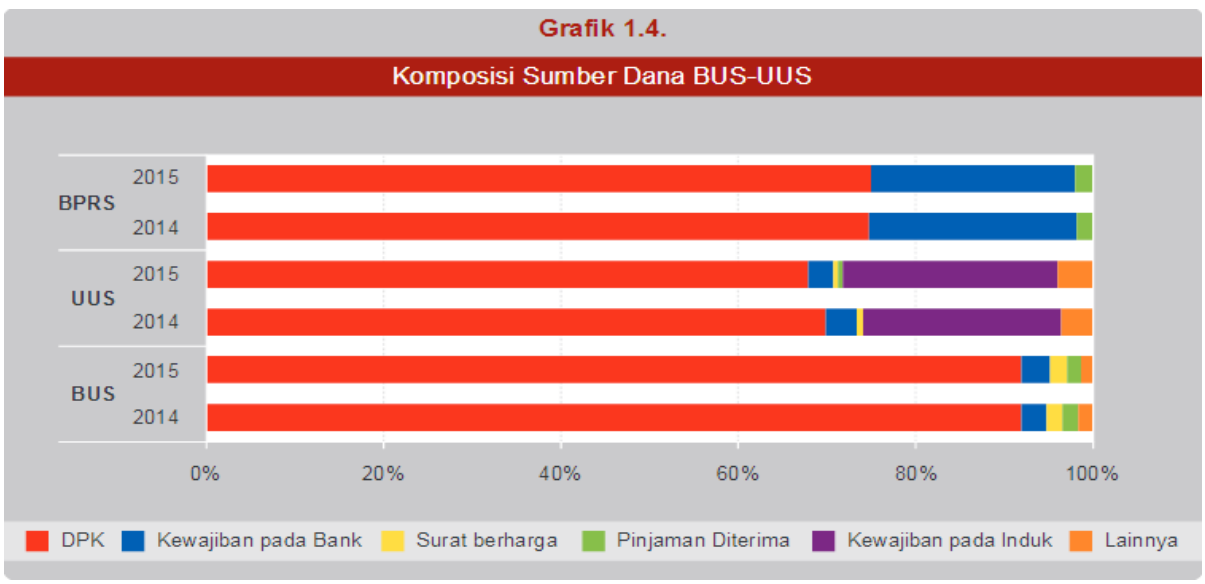

Source: 2015 Islamic Banking and Financial Progress Report

The growth of Islamic Commercial Bank Deposits is salient; the third party funds of Islamic Commercial Banks constitute the majority of funds that will be channeled to financing customers that affect the profit of Islamic Commercial Banks. Sources of funds for Islamic Commercial Banks (not including capital) are generally dominated by third parties, reaching $84.5 \%$ of the total funding sources. The amount of third party funds reflects public trust in the bank. The rise and fall of TPF is influenced by many factors, both internal factors originating from the bank itself and external factors derived from macroeconomic conditions (Mumtazah and Septiarini, 2016: 801). Macroeconomic factors referred to include inflation, interest rates (BI rate), the exchange rate of the rupiah against the US dollar, the amount of money circulating in the community. 
Figure 2. 2017 State Budget Assumptions

\begin{tabular}{|l|c|c|c|}
\hline \multicolumn{1}{|c|}{ Indikator } & $\begin{array}{c}\text { Realisasi } \\
\text { APBN 2015 }\end{array}$ & $\begin{array}{c}\text { APBNP } \\
2016\end{array}$ & APBN 2017 \\
\hline Pertumbuhan Ekonomi (\% y/y) & 4.8 & 5.2 & 5.1 \\
\hline Inflasi (\% y/y) & 3.4 & 4.0 & 4.0 \\
\hline 3-Mo Treasury (\%) & 6.0 & 5.5 & 5.3 \\
\hline Nilai Tukar (IDR / USD) & 13.392 & 13.500 & 13.300 \\
\hline ICP (USD / barel) & 50 & 40 & 45 \\
\hline Lifting minyak (Th barel / hari) & 779 & 820 & 815 \\
\hline Lifting gas (Th barel / hari) & 1.195 & 1.150 & 1.150 \\
\hline
\end{tabular}

Sumber: Kemenkeu

According to the 2016 Indonesian Economic Outlook data, Indonesia's inflation growth will be maintained. According to Mumtazah and Septiarini (2016), high inflation causes a continuous increase in prices of goods and services (not just one type of goods and a moment) (Iswardono, n.d.). Low inflation causes the prices of goods and services to decline, causing people to have excess funds to be saved in savings or invested.

The second macroeconomic factor is the interest rate (BI Rate). The high interest of customers to save is influenced by the interest rate (BI Rate). Higher the interest rate, higher the public interest in saving by expecting interest from a larger conventional bank. In an Islamic Commercial Bank, when the BI Rate is high, Islamic Commercial Banks are not permitted to increase the percentage of profit sharing in financing, because it has been agreed upon at the beginning of the contract. In this condition the Islamic Commercial Bank is faced with the condition of the risk of not competing profit sharing with Third Party Funds (Sudarwanto, 2011). In the last two years, from 2015-2016, the BI Rate was 3.4\% and 4.0\% and was below 
the benchmark interest rate set by BI which was 6.5\%. Here the researcher wants to test whether the decreasing BI Rate can increase the interest of customers in saving their funds in Islamic Commercial Banks.

The third macroeconomic factor is the rupiah exchange rate $(\mathrm{Rp})$ to the dollar (\$). Islamic banks in conducting fund collection policies are influenced by the rupiah exchange rate against the dollar. If the rupiah exchange rate against the dollar rises it will suppress demand (demand) and vice versa if the rupiah exchange rate against the dollar falls demand (demand) will increase. The fourth macroeconomic factor is the amount of money in circulation (JUB). The amount of money in circulation is the entire money circulating in the community which consists of currency and demand deposits (Iswardono, n.d.). The increase in the amount of money circulating resulted in an increase in the number of depositor funds (Maries, 2008). This article is intended to examine the influence of macro economic conditions on third party funds of Islamic Banking in Indonesia.

\section{Underlying Theory}

Third Party Funds or Deposits are funds collected by banks that come from the community in a broad sense including the community, individuals and business entities (Ismail, 2011). Deposits are collected in the form of wadiah giro, wadiah savings, mudharabah savings and mudharabah deposits. Law No.21 of 2008 concerning Islamic banking article 1 states that deposits (Third Party Funds) are funds entrusted by customers to Islamic banks and / or UUS based on wadiah agreements or other contracts that do not conflict with Islamic principles in the form of demand deposits, savings or other forms equivalent to that (Pratiwi \& Lukmana, 2015). From some of the descriptions above it can be concluded that Third Party Funds are funds collected by banks from the community in the form of savings, demand deposits, and deposits which are then used 
by banks for operational activities, including the distribution of funds to the public (Muyunda, Mee, Todd, Musonda, \& Michelo, 2018).

Inflation is briefly interpreted as a tendency to increase prices of goods and services in general and continuously (Suseno \& Astiyah, 2009). There are three important things that must be emphasized from the definition of inflation, namely:

1. There is a tendency for prices to increase

2. The price increase takes place continuously

The price level in question is the general price level, or not just one commodity. The indicator that is often used to measure the inflation rate is the Consumer Price Index (CPI). Changes in CPI from time to time indicate the price movement of the package of goods and services consumed by the public. Since July 2008, the package of goods and services in the CPI basket has been carried out on the basis of the 2007 Cost of Living Survey conducted by the Central Statistics Agency (BPS).

The BI Rate is a policy interest rate that reflects the monetary policy stance or stance set by the Indonesian bank and announced to the public (www.bi.go.id). Taking into account other factors in the economy, Bank Indonesia will generally raise the BI Rate if future inflation is expected to exceed the set target, whereas Bank Indonesia will reduce the BI Rate if future inflation is expected to be below the target set (Muttaqiena, 2013). According to the classical theory of savings is a function of interest rates where the movement of interest rates on the economy affects savings that occur (Srito, Khantanapha, \& Piriyakul, 2018). It means that people's desire to save depends very much on the interest rate. The higher the interest rate, the greater the desire of the people to save or the community will be motivated to sacrifice their expenses to increase the amount of savings so that the interest rate according to the classic is remuneration received (Alhifni, Huda, Anshori, \& Trihantana, 2017). Some argue that 
the increase in conventional interest rates led to an increase in the risk of displacement funds (transfer of funds from Islamic banks to conventional banks) faced by Islamic banks (Rivai, 2007). This caused the growth of Islamic banking third party funds (TPF) to experience a slight setback (Hamzah, 2009).

Foreign exchange rates are the price of a currency expressed in other currencies. The exchange rate is considered important because it can affect the relative price level of an export or import item(Rarick, Falk, Barczyk, $\&$ Feldman, 2012). If a country experiences a rate of exchange, it affects the price of goods produced domestically which become expensive and unreachable, while imported goods become cheaper, or vice versa if the exchange rate of a country experiences a decrease, domestically produced goods become cheap and imported goods are much more expensive (Rivai, 2007).

Depreciation of the rupiah against hard currencies such as the United States Dollar (US Dollar) can cause capital outflows or escape from public capital because if compared with other currencies, the expected return on investment in Indonesia is lower (Abdul Rahman, Muhammad, Ahmed, \& Amin, 2016). The increasing exchange rate of the US dollar will increase the demand for dollars, whereas the demand for domestic money will decrease (Amin, Rizal Abdul Hamid, Lada, \& Baba, 2009). Based on this, changes in the rupiah exchange rate against hard currencies, including the US dollar, can affect the growth of the number of accounts and deposits in Islamic banking (Muttaqiena, 2013).

Exchange rate fluctuations and expectations of large fluctuations in rupiah depreciation can cause public funds to move or run to high-quality banks and foreign banks in the country and abroad (currency substitution) (Hamzah, 2009). The turmoil will also result in bank debtors experiencing business difficulties, with the consequent consequence of being unable to 
pay the principal and interest to the bank (Ahmed, 2010). As a result, banks experience liquidity difficulties and cause an increase in the cost of funds so that banks cannot fulfill their obligations to Third Party Funds (TPF) (Sudarsono, 2009).

The money supply is the overall value of money in the hands of the people. The money supply in the narrow money is the amount of money in circulation consisting of currency and demand deposits (Ghazali et al., 2018). Technically, what counts as the money supply is money that is really in the hands of the people (Syukur \& Nimsai, 2018). Money in the hands of banks, as well as banknotes and metals belonging to the government are not counted as money supply. The money supply is another term for money supply. Money supply is a relatively new study material compared to money demand (Camillo, Marques, Holt, \& Hu, 2014). This condition is caused by the assumption that money supply can be determined directly by the central bank so that it cannot be influenced by other external factors (Ghazali et al., 2018).

In terms of terminology, there is a difference between the definitions of JUB (the amount of money in circulation) from the time of classical economics to the present. Some classical economists interpret money supply as banknotes and coins in the hands of the public (also called currency or currency) (Ahmad, Omar, Munap, \& Rose, 2018). In contrast to now the money supply is better known by several meanings, namely Narrow money, currency and demand deposit broad money, narrow money plus quasi money which include the balance of time deposits and savings deposits in banks (Hamzah, 2009). Tohari (2010) in his research concludes that the amount of money in circulation) has a positive and significant influence on TPF, the response shown by Islamic banking TPF on the money supply is the reaction of Islamic banks in seeing the development and growth of the money supply that has increased so that 
funds from the money supply can be used for financing (Al-Salim, 2009). The money supply has a positive influence on deposits in Islamic banking in Indonesia, in the sense that if the money supply increases, the TPF will also increase (Lever \& Miele, 2012).

\section{The Research Method}

The variables in this article are inflation $(\mathrm{X} 1), \mathrm{BI}$ rate $(\mathrm{X} 2)$, the rupiah exchange rate against the US dollar (exchange rate) (X3), the money supply (X4), and Third Party Funds or DPF (Y). The population in this article is Islamic banking data published by Bank Indonesia in its monthly report (Rivai, 2007). Where the sample taken uses all the existing population as many as 48 samples (data) which are monthly data on Inflation, Third Party Funds (TPF) of Islamic Banking, BI rate, Exchange Rate of Rupiah against US Dollar, and Amount of Money Supply from 2013 to 2016.

Third Party Funds or Deposits are funds collected by banks that come from the community in a broad sense including the community (Pratiwi \& Lukmana, 2015), individuals and business entities (Ismail, 2011). Deposits are collected in the form of wadiah giro, wadiah savings, mudharabah savings and mudharabah deposits.

Formula:

$$
\sum \mathrm{TPF}=\mathrm{SW}+\mathrm{SM}
$$

¿TPF : Amount of Third Party Funds

SW : Wadiah Deposits (Current Accounts, Savings Accounts)

SM : Mudharabah Deposits (Savings, Deposits)

The indicator that is often used to measure the inflation rate is the Consumer Price Index (CPI). The formula used is as follows: 


$$
\operatorname{Inf}=\frac{(\mathrm{IHK} n)-(\mathrm{IHK} \mathrm{n}-1)}{(\mathrm{IHK} \mathrm{n}-1)} \times 100 \%
$$

Inf : Inflation

CPI $n \quad$ : CPI of the month in question

CPI n-1 : CPI the previous month

Exchange rate is a comparison of a country's currency exchange rate with a foreign currency or a comparison of exchange rates between countries. While the rupiah exchange rate against the US dollar is a comparison of the rupiah exchange rate against the US dollar.

Middle exchange rate $=$ selling rate + buying rate 2

The money supply in the narrow money is the amount of money in circulation consisting of currency and demand deposits.

$$
\mathrm{M} 1=\mathrm{C}+\mathrm{D}
$$

M1 : money supply in a narrow sense

C : Banknotes

D : Check money or check

Broad money in the broad sense (M2) is added to time deposits.

$$
\mathrm{M} 2=\mathrm{M} 1+\mathrm{TD}
$$

M2 : The amount of money in circulation in a broad sense

TD : Time deposits 
The data analysis technique used in this study is testing the model of multiple linear regression equations. Systematically the regression equation can be made as follows:

$\mathrm{TPF}=\alpha 0+\beta_{1} \operatorname{Inf}+\beta_{2}$ BIrate $+\beta_{3}$ Kurs $+\beta_{4} \mathrm{JUB}+\mathrm{e}$

TPF : Third Party Funds

Inf : Inflation

Birate : BI rate

Exchange rate : Rupiah exchange rate against dollar

JUB : Amount of Money Circulating

$\beta 1, \beta 2, \beta 3, \beta 4$ : The regression coefficients of each independent variable

$\alpha 0 \quad$ : Constants

e : Error

\section{Analyzing the Relations}

Quantitative data on Third Party Funds (TPF), inflation / CPI (Consumer Price Index), BI Rate, Exchange Rate, and Amount of Money Supply (JUB) are obtained through Bank Indonesia monthly reports. Based on the data that has been processed using SPPS 23, descriptive statistics are obtained as follows:

Table 1. Descriptive Statistics

\begin{tabular}{l|r|r|r|r|r}
\hline & N & Minimum & Maximum & \multicolumn{1}{c}{ Mean } & Std. Deviation \\
\hline TPF & 48 & 3205006 & 4836758 & 4023479,40 & 474404,576 \\
INF & 48 &,- 0045 &, 0329 &, 004692 &, 0066819 \\
BI_RATE & 48 &, 0475 &, 0775 &, 069010 &, 0090615 \\
KURS & 48 & 9687 & 14396 & 12253,19 & 1327,853 \\
JUB & 48 & 3268789 & 5004977 & 4097457,60 & 495639,979 \\
Valid N (listwise) & 48 & & & & \\
\hline
\end{tabular}

Source: data processed, 2016 
Based on table 1 above, it is known that $\mathrm{N}$ or the total amount of data in this study amounted to 48 pieces. The processed data is known as the lowest and highest value, average and standard deviation of the variables of TPF, inflation / CPI, BI rate, and JUB.

Before we test multiple linear regression analysis, the data is tested using the classic assumption test so that the results in this study are valid and unbiased. Classical assumptions used are normality test, multicollinearity test, autocorrelation test, and heteroscedasticity test.

\section{Normality Test}

To see whether the data is normally distributed or not, normality is tested using the One-Sample Kolmogorov-Smirnov Test. After the data is processed using the SPSS 23 application, the following results are seen:

Table 2. One-Sample Kolmogorov-Smirnov Test

\begin{tabular}{ll|r}
\hline & & \multicolumn{2}{|c}{$\begin{array}{c}\text { Unstandardized } \\
\text { Residual }\end{array}$} \\
\hline $\mathrm{N}$ & Mean & 48 \\
Normal & Std. Deviation & 23616,25185951 \\
Parameters & Absolute &, 062 \\
Most Extreme & Abson &, 062 \\
Differences & Positive &,- 055 \\
& Negative &, 062 \\
Test Statistic & &, $200^{\text {c,d }}$ \\
Asymp. Sig. (2-tailed) &
\end{tabular}

Source: secondary data, processed (2016)

The test results show that the significance value is $0.200>0.05$, then the data is normally distributed, so that it can proceed to the next test. 


\section{Multicollinearity Test}

The results of multicollinearity testing are as follows:

Table 3. Multicollinearity Test Results

\begin{tabular}{l|l|r|r}
\hline \multicolumn{2}{c|}{ Model } & \multicolumn{2}{c}{ Collinearity Statistics } \\
\cline { 3 - 4 } \multicolumn{2}{c}{1} & Tolerance & \multicolumn{1}{c}{ VIF } \\
\cline { 2 - 4 } & (Constant) & & \\
\cline { 2 - 4 } & INF &, 858 & 1,166 \\
\cline { 2 - 4 } & BI_RATE &, 286 & 3,497 \\
\cline { 2 - 4 } & KURS &, 051 & 19,677 \\
\cline { 2 - 4 } & JUB &, 053 & 18,836 \\
\hline
\end{tabular}

a. Dependent Variable: TPF

Source: secondary data, processed (2018)

The test results show that all variables used as predictors of the regression model show the VIF value of the exchange rate and JUB above 10. This shows the presence of symptoms of multicollinearity. However, in the opinion of Geary R.C as quoted by Gujarati (1993) states that if the only purpose of regression analysis is to predict, then multicollinearity is not a serious problem so the regression model can be further analyzed. But this is only true if multicollinearity between variables in the research sample will also remain in the future.

\section{Autocorrelation test}

According to Sunyoto (2007: 104-105), one measure to determine whether there is an autocorrelation problem with the Durbin Watson (DW) test with the following conditions: 
1) A positive autocorrelation occurs if the DW value is below -2 (DW $<-2)$

2) There is no autocorrelation if the DW value is between -2 and +2 $(-2<\mathrm{DW}<2)$

3) Negative autocorrelation occurs if the DW value is above 2 (DW> 2)

Table 4. Durbin Watson's Test Results

\begin{tabular}{l|l|r|r|r}
\hline Model & \multicolumn{1}{|c|}{ R } & R Square & $\begin{array}{c}\text { Adjusted R } \\
\text { Square }\end{array}$ & Durbin-Watson \\
\hline 1 &, $999^{\mathrm{a}}$ &, 998 &, 997 &, 991 \\
\hline
\end{tabular}

a. Predictors: (Constant), JUB, BI_RATE, INF, KURS

b. Dependent Variable: TPF

The results of autocorrelation testing using the Durbin Watson test (DW test) showed that DW of 0.991 was between -2 and $2(-2<\mathrm{DW}<2)$ so autocorrelation did not occur which meant passing the autocorrelation test.

\section{Heteroscedasticity test}

Heteroscedasticity testing uses scatterplot graphics. Following are the results of testing heteroscedasticity: 


\section{Figure 3. Scatterplot Graph Test Results}

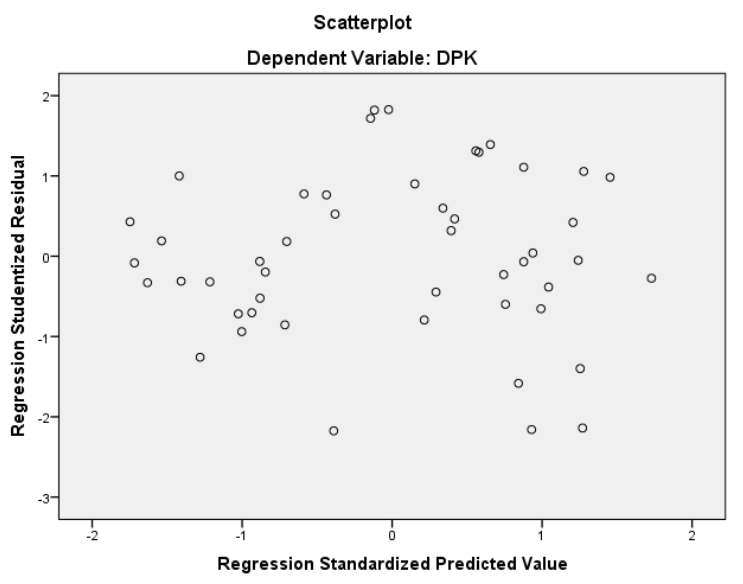

Source: secondary data, processed (2016)

Heteroscedasticity testing results shows that the regression model does not contain heteroscedasticity. This can be made a decision that there are no specific patterns such as the existing dots form a regular pattern (wavy, then narrow) so there is no heteroscedasticity.

\section{Determination Coefficient}

The coefficient of determination will later measure how far the ability of the model in explaining dependent variation. The estimated relationship between variables that affect the amount of TPF can be shown as follows:

Table 5. Multiple Linear Regression Results

\begin{tabular}{l|c|r|r}
\hline Model & $\mathrm{R}$ & \multicolumn{1}{c|}{$\mathrm{R}$} & \multicolumn{1}{c}{$\begin{array}{c}\text { Adjusted R } \\
\text { Square }\end{array}$} \\
\hline 1 &, $999^{\mathrm{a}}$ &, 998 &, 997 \\
\hline
\end{tabular}

a. Predictors: (Constant), JUB, BI

RATE, INF, KURS

b. Dependent Variable: TPF

Source: Secondary data, processed (2016) 
Based on the table above, the value (Adj $\mathrm{R}^{2}$ ) is 0.997 or $99.7 \%$. This shows that the variation of the independent variables used in the model is able to explain $99.7 \%$ of the variation of the dependent variable. While the remaining $0.3 \%$ is explained by other variables.

\section{F Statistical Test (Model Accuracy Test)}

F statistic test basically shows whether all independent or independent variables entered into the model have a joint influence on the dependent or dependent variable (Ghozali, 2006).

Table 6. Statistical Test Results F

\begin{tabular}{ll|l|l}
\hline & Model & F & Sig. \\
\hline 1 & Regression & 4327,197 &, $000^{\mathrm{b}}$ \\
& Residual & & \\
& Total & & \\
\hline
\end{tabular}

a. Dependent Variable: TPF

b. Predictors: (Constant), JUB, BI_RATE, INF, KURS

Source: Secondary data, processed (2016)

From $\mathrm{F}$ test in table 4.12 above, it obtained $\mathrm{F}_{\text {coun }} \mathrm{t}>\mathrm{F}_{\text {Tabel }}$ is $4327.197>2.432236$ with a significance of $0.000<0.05$. This can mean that inflation, the BI Rate, exchange rate and the money supply together influence the number of Islamic bank deposits. This $\mathrm{F}$ test also means that the selection of the inflation variable, BI Rate, exchange rate and the money supply as a predictor of Islamic banking deposits is right.

The regression equation model can be written from the table above as follows:

$$
\begin{aligned}
\text { TPF }= & -65.168,304-1.038 .739 \mathrm{INF}+2.303 .969,572 \mathrm{BI} \_ \text {RATE }+ \\
& 1,931 \mathrm{KURS}+0,954 \mathrm{JUB}+\mathrm{e}_{\mathrm{r}}
\end{aligned}
$$


TPF: Third Party Funds

INF: Inflation

BI_RATE: BI Rate

EXCHANGE: Rupiah Currency Exchange Rate against US Dollar JUB: Amount of Money in circulation

$\beta 1, \beta 2, \beta 3, \beta 4$ : The regression coefficients of each independent variable

$\alpha 0$ : Constants

er: Error

Table 7. Hypothesis Analysis Results

\begin{tabular}{l|r|r|l|l|l|l}
\hline & $\begin{array}{l}\text { Regression } \\
\text { coefficient }\end{array}$ & t-count & t Table & Sign & Result & Description \\
\hline Constants & $-65.168,3$ & & & & & \\
\hline Inflation & $-1.038 .739,8$ & $-1,785$ & 2,01669 & 0,081 & Reject H1 & No effect \\
\hline Bi Rate & $2.303 .969,6$ & 3,100 & 2,01669 & 0,003 & $\begin{array}{l}\text { Accept } \\
\text { H2 }\end{array}$ & Berpengaruh \\
\hline $\begin{array}{l}\text { Rupiah exchange } \\
\text { rate against US } \\
\text { dollar (exchange } \\
\text { rate) }\end{array}$ & 1,931 & 0,161 & 2,01669 & 0,873 & Reject H3 & No effect \\
\hline $\begin{array}{l}\text { Total money } \\
\text { supply }\end{array}$ & 0,954 & 30,266 & 2,01669 & 0,000 & $\begin{array}{l}\text { Accept } \\
\text { H4 }\end{array}$ & Take effect \\
\hline
\end{tabular}

Source of data: data processed by SPSS (2016)

\section{Analyzing the Influences}

Hypothesis testing 1 in this article is intended to find out whether there is an influence between inflation on the amount of Third Party Funds (TPF). In the regression table obtained the value for the inflation 
variable of 2.01669 with a significance of $0.081>0.05$, the first hypothesis is rejected, meaning that inflation does not significantly influence TPF in Islamic Commercial Banks in Indonesia. The results showed that inflation had no effect on TPF with a significance value of 0.081 then $\mathrm{H} 1$ was rejected at a significance level of 5\%. The regression results of the inflation variable have a regression coefficient of -1.038 .739 .8 with a negative direction, which means that an increase in inflation will reduce the Third Party Fund of Islamic Commercial Banks.

This article findings may be discussed with such research as Shafiq (2016), (Ferdiansyah, 2015), Hermanto (2008) which states that inflation does not affect Islamic Bank Third Party Funds (TPF), and is contrary to the results Salviana (2014) which states that inflation has a significant effect on TPF. Testing of hypothesis 2 in this study is intended to find out whether there is a significant and significant influence of BI Rate on the amount of TPF. In the regression table is obtained the value for the BI Rate of 3.100 with a significance of $0.003<0.05$, then the hypothesis is accepted, meaning that the BI Rate has a significant effect on the positive direction of TPF in Islamic Commercial Banks.

The results show that the interest rate (BI Rate) affects TPF with a significance value of 0.003 , so $\mathrm{H} 2$ is received at a significance level of 5\%. This shows TPF depends on the BI Rate. The BI Rate has a regression coefficient of 2,303,969.6, meaning that the BI rate has a positive relationship with the number of Islamic Commercial Bank TPF. The increase in interest rates (BI rate) on Islamic Commercial Banks is predicted to increase TPF at Islamic Commercial Banks. The interest rate (BI rate) has a positive effect on the amount of Third Party Funds where the increase in profit sharing rates attracts customers to save funds in Islamic banking. This result does not support the statement of the Islamic Banking Director, Ramzi A Zuhdi said, "Usually in general, if the BI Rate falls, 
Third Party Funds (TPF) will rise, running from conventional banking to Islamic Banks" (Prasetyoningrum, 2015). Comparing this article finding to Prasetyoningrum (2015) where the interest rate (BI Rate) has an insignificant effect but has a negative direction to TPF. The results of this article are also different from Hermanto (2008) research which states that the interest rate (BI Rate) has a significant effect but with a negative direction on TPF.

The testing of hypothesis 3 in this article is intended to find out whether there is a significant influence between the rupiah exchange rate and the US dollar (exchange rate) on TPF. In the regression table obtained th value for the exchange rate variable is 0.161 with a significance of $0.873>$ 0.05 , then hypothesis 3 is rejected. This means that the exchange rate does not have a significant effect on TPF in Islamic Commercial Banks. The results shows that the rupiah exchange rate against the US dollar (exchange rate) had no significant effect on TPF. The regression coefficient of the exchange rate variable is 1.931 with a positive direction. This means that every exchange rate increase is predicted to increase the collection of Third Party Funds of Islamic Commercial Banks. This happens because people prefer to save their money in Islamic banking when the dollar rises rather than spend it. This result is different from the results of research by Pratiwi \& Lukmana (2015) and Salviana (2014) which state that the exchange rate has a positive and significant effect on the amount of TPF.

Testing the hypothesis 4 in this study is intended to find out the money supply (JUB) and the amount of TPF. In the regression table obtained by the value for the variable money supply (JUB) of 30.266 with a significance of $0.000<0.05$, the hypothesis is accepted. The money supply (JUB) has a significant effect on the positive direction of TPF in Islamic Commercial Banks. The results of testing hypothesis can prove that the hypothesis supports a positive and significant relationship between the 
money supply (JUB) and TPF. The results of testing hypothesis 4 are in line with the findings of Shafiq (2016). This means that if the value of JUB gets bigger, the TPF in Islamic Banking will be greater. The results of this research can be explained by the amount of money circulating in the community is high, resulting in inflation and a decline in the purchasing power of the rupiah. The decline in the value of the rupiah resulted in people reluctant to do business and chose to keep it in the bank (Tohari, 2010). So there is an increase in banking deposits, including in this study is Islamic banking.

F statistic test basically shows whether all independent or independent variables entered into the model have a joint influence on the dependent or dependent variable (Ghozali, 2006). The results of the statistical test $\mathrm{F}$ are as follows:

Table 8. The results of the $\mathrm{F}$ test hypothesis analysis

\begin{tabular}{l|c|c|c|c}
\hline & $\begin{array}{c}\text { F } \\
\text { hitung }\end{array}$ & Sign & Ket & \multicolumn{1}{|c}{ Hasil } \\
\hline $\begin{array}{l}\text { Variabel } \\
\text { secara } \\
\text { simultan }\end{array}$ & 4327,2 & 0,000 & $\begin{array}{l}\text { Terima } \\
\text { H5 }\end{array}$ & $\begin{array}{l}\text { Berpengaruh } \\
\text { Signifikan }\end{array}$ \\
\hline
\end{tabular}

Source: data processed by SPSS (2018)

From the $\mathrm{F}$ test in table 4.12. above obtained $\mathrm{F}_{\text {count }}>\mathrm{F}_{\text {Tabel }}$ is $4327.197>2.432236$ with a significance of $0.000<0.05$. This can mean that inflation, the BI Rate, exchange rate and the money supply together influence the number of Islamic bank deposits. This $\mathrm{F}$ test also means that the selection of the inflation variable, BI Rate, exchange rate and the money supply as a predictor of Islamic banking deposits. 


\section{Conclusion}

Based on the results of data analysis, hypothesis testing, and discussion, the following conclusions can be drawn. The inflation variable does not affect TPF in Islamic Commercial Banks in Indonesia. The BI Rate variable has a significant effect on the positive direction of the amount of TPF in Islamic Commercial Banks. This shows TPF depends on the BI Rate. The increase in interest rates (BI rate) on Islamic Commercial Banks is predicted to increase the amount of TPF in Islamic Commercial Banks. Interest rates (BI rate) have a positive effect on the amount of mudharabah savings where an increase in profit sharing rates attracts customers to save funds. The exchange rate variable does not have a significant effect on TPF in Islamic Commercial Banks. The results of this research can be explained that the amount of money circulating in the community is high, resulting in a decrease in the purchasing power of the rupiah. The decline in the value of the rupiah resulted in people reluctant to do business and chose to keep it in the bank. To conclude, there is an increase in banking deposits, including in this study is Islamic banking. Inflation variables, the BI rate, the exchange rate of the rupiah against the US dollar (exchange rate), and the money supply together influence the TPF. Consequently, the selection of the inflation variable, BI rate, rupiah exchange rate against US dollar (exchange rate), and the money supply as a predictor of TPF in Islamic Commercial Banks in 2003-2016 was correct.

In subsequent studies it is expected to use other objects. It is expected that in the research, the research variables will be added, such as national income. It is expected that Islamic banking will consider the BI interest rate (BI rate) and the money supply and in line with this research the $\mathrm{BI}$ interest rate (BI rate) and the money supply have a significant effect on the positive direction of third party Islamic Banks, if there is a decrease in the money supply, it will result in a reduction in the amount of Third 
Party Funds. It is expected that policy makers, to evaluate and strengthen macroeconomic developments (especially BI interest rates (BI rate) and the money supply) so that Islamic banking is resistant to the shock of the monetary crisis that occurred in Indonesia.

Vol. 3 No. 1, January - April 2018 


\section{References}

Abdul Rahman, R., Muhammad, A. D., Ahmed, S., \& Amin, F. (2016). Micro-entrepreneurs' intention to use Islamic micro-investment model (IMIM) in Bangladesh. Humanomics, 32(2), 172-188. https:// doi.org/10.1108/H-02-2016-0020

Ahmad, S. N. B., Omar, A., Munap, R., \& Rose, R. M. (2018). Influence of consumers' perceived brand innovativeness on customer-brand identification and brand loyalty. International Journal of Supply Chain Management, 7(4), 145-150.

Ahmed, A. M. E. T. (2010). Islamic banking: How to manage risk and improve profitability (Vol. 640). John Wiley \& Sons.

Alhifni, A., Huda, N., Anshori, M., \& Trihantana, R. (2017). WAQF an instrument of community empowerment in Islamic Boarding School Daarut Tauhiid in Indonesia. Journal of Islamic Economics, Banking and Finance, 13(2), 76-88.

Al-Salim, F. H. (2009). Islamic Financial Product Innovation. International Journal of Islamic and Middle Eastern Finance and Management.

Amin, H., Rizal Abdul Hamid, M., Lada, S., \& Baba, R. (2009). Cluster analysis for bank customers' selection of Islamic mortgages in Eastern Malaysia: An empirical investigation. International Journal of Islamic and Middle Eastern Finance and Management, 2(3), 213-234. https:// doi.org/10.1108/17538390910986344

Camillo, A. A., Marques, J., Holt, S., \& Hu, J. (2014). Creating global competitiveness through culture and religion: An insight into the global strategic evolution and marketing of the halal food industry. In Handb. of Res. on Eff. Mark. in Contemp. Glob. (pp. 335-347). IGI Global. https://doi.org/10.4018/978-1-4666-6220-9.ch019

Ferdiansyah. (2015). Pengaruh Rate Bagi Hasil Dan Bi Rate Terhadap Dana Pihak Ketiga Perbankan Syariah (Studi Pada Bank Pembiayaan Rakyat Syariah Yang Terdaftar Di Bank Indonesia). Jurnal Jom Fekon, 2(1). 
Ghazali, P. L., Guci, D. A., Jaaffar, S. A. S., Simbolon, R., Elviani, S., Abas, S., ... Mamat, M. (2018). Critical success factor of demand towards new product of Islamic home financing: A pilot test. International Journal of Engineering and Technology(UAE), 7(3.28 Special Issue 28), 189-190.

Ghozali, I. (2006). Aplikasi Analisis dengan Program SPSS. Semarang: Undip.

Hamzah, M. (2009). Optimalisasi Peran Dual Banking System Melalui Fungsi Strategis JUB Dalam Rangka Menjaga Stabilitas Sistem Keuangan di Indonesia. Jurnal Ekonomi Islam, 3 (2)., (3), 2.

Hermanto. (2008). Faktor-faktor yang Mempengaruhi Dana Pihak Ketiga (DPK) Bank Umum Syariah Tahun 2005-2007. Skripsi Fakultas Ekonomi Dan Bisnis, UIN Syarif Hidayatullah.

Ismail. (2011). Perbankan Syariah. Jakarta: Kencana.

Iswardono. (n.d.). Uang dan Bank. Yogyakarta: BPFE-Yogyakarta.

Lever, J., \& Miele, M. (2012). The growth of halal meat markets in Europe: An exploration of the supply side theory of religion. Journal of Rural Studies, 28(4), 528-537. https://doi.org/10.1016/j. jrurstud.2012.06.004

Maries, R. (2008). Dampak Fluktuasi Variabel Ekonomi Makro Terhadap DPK Yang Dibimpun Dan Penyaluran Pembiayaan Pada Perbankan Syariah Di Indonesia (Tesis.). Universitas Indonesia, Jakarta.

Muttaqiena, A. (2013). Analisis Pengaruh PDB, Inflasi, Tingkat Bunga, Dan Nilai Tukar Terhadap Dana Pihak Ketiga Perbankan Syariah Di Indonesia 2008-2012. Economics Development Analysis Journal.

Muyunda, B., Mee, P., Todd, J., Musonda, P., \& Michelo, C. (2018). Estimating levels of HIV testing coverage and use in prevention of mother-to-child transmission among women of reproductive age in Zambia. Archives of Public Health, 76(1). https://doi.org/10.1186/ s13690-018-0325-x 
Prasetyoningrum, Ari Kristin. (2015). Analysis BI Rate and Return of Third Party Fund On Rate of Third PartyFund onIslamic Banking in Indonesia (Vol. 2). Presented at the Conference in Business and Management, Universitas Islam Sultan Agung.

Pratiwi, R., \& Lukmana, A. (2015). Pengaruh Kurs Valuta Asing dan Tingkat Bagi Hasil Terhadap Volume Depositi Mudharabah USD pada Perbankan Syariah (Periode Januari 2011-Maret 2015). Jurnal Ekonomi Dan Perbankan Syariah, 3(1).

Rarick, C., Falk, G., Barczyk, C., \& Feldman, L. (2012). Marketing to muslims: The growing importance of halal products. Journal of the International Academy for Case Studies, 18(1), 81-86.

Rivai, V. (2007). Bank and fianancial Institution Management (Conventional) and Islamic System. Jakarta: PT Grafindo Persada.

Salviana. (2014). Analisis Pengaruh Tingkat Inflasi, Kurs dan Nisbah Bagi Hasil terhadap Dana Pihak Ketiga (DPK) Perbankan Syariah di Indonesia (Desember 2010-Juli 2013). (Skripsi. Fakultas Ekonomi dan Bisnis). UIN Syarif Hidayatullah Jakarta., Jakarta.

Shafiq, M. . (2016). Pengaruh Inflasi Dan Jumlah Uang Beredar Terhadap Dana Pihak Ketiga (DPK) Mudharabah Pada Bank Syariah Mandiri (BSM) Tahun 2010-2015 (Skripsi). Universitas Islam Negeri Walisongo.

Srito, S. N., Khantanapha, N., \& Piriyakul, R. (2018). Inclusive business management for supporting a community economy in Bangkok Area. International Journal of Management and Business Research, 8(2), 2836.

Sudarsono, H. (2009). Dampak Krisis Keuangan Global Terhadap Perbankan Di Indonesia: Perbandingan Antara Bank Konvensional Dan Bank Syariah. Jurnal Ekonomi Islam La Riba, 3.

Sudarwanto, B. (2011). Dampak Penurunan BI Rate bagi Perbankan Syariah. Retrieved from http://id.beritasatu.com/home/dampakpenurunan-bi-rate-bagi-perbankan-syariah/22227 diakses tanggal 8 Juni 2017 pukul 13:02 
Suseno, \& Astiyah, S. (2009). Inflasi. Jakarta: Bank Indonesia.

Syukur, M., \& Nimsai, S. (2018). Factors influencing the purchase intention of halal packaged food in Thailand. International Journal of Supply Chain Management, 7(4), 1-6. 
152 Anik, Iin Emy Prastiwi

Vol. 3 No. 1, January - April 2018 


\section{Shirkah Author Guidelines}

Shirkah currently offers two routes to submit manuscripts. We highly recommend to submit the articles which are made using OJS (Open Journal System). Feel free register as author soon through visiting http:// shirkah.or.id/index.php/home/user/register. The authors may directly send their manuscripts, along with their resume, to shirkahiainsurakarta@ gmail.com. Please prepare your manuscripts, using following guidelines:

1. Manuscript must be written in English. Submitted articles should not have been published or be under review for publication with another journal.

2. Manuscript's length is about $15-20$ pages, typed in one-half spaced on A4-paper size.

3. Manuscript must include an $150-200$ word abstract and keywords.

4. Manuscript must be arranged as follows: Title, Name of Author, E-mail address, Abstract, Keywords, Introduction (including method if any), Discussion, Conclusion, References.

5. Manuscript's titles not more than ten words.

6. Manuscript must be submitted in Microsoft Word or RTF.

7. Arabic words should be transliterated according to the style of International Journal of Middle Eastern Studies.

8. Manuscript references are preferably derived from the up-to-date references.

9. The author's resume should be submitted separately, consisting of at least full name, institutional address, phone number, areas of studies, and recent publications (if any).

10. Shirkab use APA Style 6th edition (2010) as reference format writing. We suggest the use of a reference manager software such as Mendeley, Zotero, and Endnote at templating the citation style. APA Style to be used is as follows: 


\section{Book with single author}

Swann, G. M. Peter. (2014). The Economics of Innovation an Introduction. Cheltenhum \& Northampton: Edward Elgar.

in-text citation: (Swann, 2014)

\section{Articles in reference books}

Alatas, S. F. (2006). Islam and the Science of Economics in Abu Rabi', I.M. The Blackwell Companion to Contemporary Islamic Thought. USA: Willey-Blackwell (pp. 587-606).

in text citation: (Alatas, 2006)

\section{E-Book}

Hackett, Rosalind (2007). "Religous Dimentions of War and Peace: Introduction.” Dalam Gerrie ter Haar dan Yoshio Tsuruoka (Ed.), Religion and Society: An Agenda for the 21st Century (h. 3-6). Retrieved from http:// brill.nl.

in text citation: (Hackett, 2006)

\section{Master's thesis, from a commercial database}

McNieI, D. S. (2006). Meaning through narrative: A personal narrative discussing growing up with an alcoholic mother (Master's thesis). Available from ProQuest Dissertations and Theses database. (UMI No. 1434728)

in text citation: (Mc Niel, 2006)

\section{Doctoral dissertation, from an institutional database}

Adams, R. J. (1973). Building a foundation for evaluation of instruction in higher education and continuing education (Doctoral dissertation). Retrieved from http://www.ohiolink.edu/etd/

in text citation: (Adams, 1973) 


\section{Doctoral dissertation, from the web}

Bruckman, A. (1997). MOOSE Crossing: Construction, community, and learning in a networked virtual world for kids (Doctoral dissertation, Massachusetts Institute of Technology). Retrieved from http:/www-static. cc.gatech.edu/--asb/thesis/

in text citation: (Bruckman, 1997)

\section{Journal article with No DOI}

Bourkhis, K., and Nabi, M. S. (2013). Islamic and conventional banks' soundness during the 2007-2008 financial crisis. Journal Metrics, 22(2), 68-77.

in-text citation: (Bourkhis \& Nabi, 2013).

\section{Journal article with DOI}

Ichwan, M. (2012). The Local Politics Of Orthodoxy: The Majelis Ulama Indonesia in the Post-New Order Banten. Journal Of Indonesian Islam, 6(1), 166-194. doi:http://dx.doi.org/10.15642/JIIS.2012.6.1.166-194

In text citation : (Ichwan, 2012)

\section{Abstract as citation}

Hasan, N. (2012). Islamist Party, Electoral Politics And Da'wah Mobilization Among Youth : The Prosperous Justice Party (PKS) in Indonesia. Journal of Indonesian Islam, 6(1), 17-47. Abstract from http:// jiis.uinsby.ac.id/index.php/jiis/article/view/97

in text citation : (Hasan, 2012)

\section{Mass media article}

Sahal, Akhmad (2014, March 2). Kiai Sahal dan Realisme Fikih.Tempo Magazine, p. 120.

in text citation : (Sahal, 2014) 


\section{Research report}

Fisher, B. S., Cullen, F. T., \& Turner, M. G. (2000). The Sexual Victimization of College Women. Research Report.

in text citation : (Fisher, Cullen, Turner, 2000)

\section{Monograph}

Routray, Bibhu Prasad (2013), National Security Decision-Making in India (RSIS Monograph No. 27). Singapura: Rajaratnam School of International Studies.

in text citation : (Routray, 2013)

\section{Proceeding article}

Sudibyakto, Hizbaron, D.R., \& Jati, R (Ed.) (2009), Proceeding International Seminar Disaster Theory, Research and Policy. International seminar held by Sekolah Pascasarjana, Universitas Gajahmada, Yogyakarta, 8-9 Desember 2009.

in text citation : (sudibyakto and Jati, 2009)

\section{Paper conference/seminar/symposium}

Janutama, Herman Sinung (2011). "Kraton dan Hubungan Antar Agama." Paper presented in Seminar Kraton dan Panatagama held by Center for the Study of Islam and Social Transformation (CISForm), Yogyakarta, 17 November.

in text citation :(Janutama, 2011)

\section{Online article in web}

Shiva, (2006, February). Bioethics: A Third World Issue. Native-web. Diperoleh dari http://www.nativeweb.org/ pages/legal/shiva.html

in text citation : (Shiva, 2006) 


\section{Online research report}

Kessy, S. S. A., \& Urio, F M. (2006). The contribution of microfinance institutions to poverty reduction in Tanzania (Research Report No. 06.3). Retrieved from Research on Poverty Alleviation website: http://www. repoa.or.tz /documents_storage/Publications/Reports/06.3_Kessy_and_ Urio.pcif

in text citation : (kessy and urion, 2006)

\section{Holy book}

Qur an, $2(25)$

In text citation : (Q. al-Baqarah 2:25).

\section{Encyclopaedia}

Graycar, Adam (1992). Social Welfare Policy. Dalam Mary Hawkesworth dan Maurice Kogan (Ed.), Encyclopedia of Government and Politics (Vol. 1). London: Routledge.

in text citation : (Graycar, 1992)

\section{Interview}

Sultan Hamengkubuwono X (interview, 2011, April 19)

in text citation: (Hamengkubuwono, 2011)

\section{Documentary film}

Steijlen, Fridus (2008). A Day in the Life of Indonesia [documentary film, 58 minutes]. Leiden: KITLV Press.

in text citation : (Steijlen, 2008) 
Vol. 3 No. 1, January - April 2018 